\title{
Assessment on Prevalence and Distribution of Diseases of Rice in Kymore Plateau and Satpura Zone of Madhya Pradesh
}

\author{
T. Ramya Teja ${ }^{*}$, Prahallad Masurkar, M.S. Bhale and G.K. Koutu \\ Department of Plant Pathology, College of Agriculture, JNKVV, \\ Jabalpur, 482004, M.P., India \\ *Corresponding author
}

\begin{tabular}{|l|}
\hline K e y w o r d s \\
$\begin{array}{l}\text { Rice, Sheath blight, } \\
\text { Brown spot, Disease } \\
\text { incidence, Survey, Grain } \\
\text { discoloration }\end{array}$ \\
\hline Article Info \\
\hline $\begin{array}{l}\text { Accepted: } \\
18 \text { October } 2018 \\
\text { Available Online: } \\
10 \text { November } 2018\end{array}$ \\
\hline
\end{tabular}

\section{A B S T R A C T}

Investigations were made to determine the status of major targeted diseases of rice in different locations grown in agro climatic conditions of Jabalpur. With a view to determine the status of diseases in rice crop, survey was made in kymore plateau and satpura zone of Madhya Pradesh. Six different locations around Jabalpur (Panagar, Maharajpur, Patan road, Damoh road, Tilwara, Bhedaghat) and Seed production units at COA, Jabalpur were surveyed through random plot and fixed field survey method. Percent disease incidence was recorded on randomly selected 50 plants in a particular field of that location. In each village five randomly road side rice fields were selected. The incidence of diseases was observed on the basis of typical field symptoms and later the association was confirmed through microscopic examinations under lab condition. The incidence of sheath blight was higher in Panagar and Maharajpur. Least number of infected plants were observed in Maharajpur, Patan road, Damoh road and Tilwara. Grain discoloration was observed in range of $5.0-17.0 \%$ at six locations. The incidence of neck blast was observed in one field of Damoh road and Bhedaghat in the range of 7.0-10.0\%. It was found that variety Kranti was the most susceptible to all the seven diseases at different seed production units with highest range of 4.0-5.0\%.

\section{Introduction}

Rice (Oryza sativa L., Family: Poaceae) is the world's most important crop, staple food for more than half of the world's population and its production has direct effect on food security. In India, rice covers $43.8 \mathrm{~m}$ ha area of which Madhya Pradesh occupies $14.9 \mathrm{~m}$ ha. In M.P. this area include $2.37 \mathrm{~m}$ ha under irrigated, $2.63 \mathrm{~m}$ ha under upland and $9.94 \mathrm{~m}$ ha under drought prone rainfed lowland agroecosystem (Pathak et al., 2011). The crop can be grown in different ecologies depending upon water availability as lowland rainfed, lowland irrigated, deep water, coastal wet land and upland rice (http://wikipedia.org/wiki/ rice). In India rice is grown from $8^{\circ} \mathrm{N}$ to $34^{\circ} \mathrm{N}$ latitude including 5 rice ecosystem (icar.org).

Rice crop is currently challenged by different biotic and abiotic factors. The biotic factors like fungi, bacteria, virus and nematode diseases have been reported on rice crop in the world. Diseases are considered major constraints in rice production and responsible for losses in quantity and quality of harvested 
produce. Important diseases cause crop damage severe enough to make control measures an economic necessity. Estimated losses can range from 1- 100\% depending on the nature of the disease, stage of plant growth at infection, resistance of the variety, management and weather conditions.

A susceptible host plant, a virulent pathogen and a favorable environment are the three factors composing the plant disease triangle (John and Fielding, 2014). All three factors are necessary for development of a plant disease; thus, disease can be affected by altering any of these three factors. Diseases cause the alters of the normal physiological activity of a plant; that affects some or all plant functions and may reduce the quality and/or quantity of the harvested product (Mueller et al., 2010). The growth and productivity of rice is dependent mainly on the influence of both biotic and abiotic factors.

A number of plant pathogens infect the crop (Singh 2004; Agrios 2009). Important fungal pathogens are blast (Magnaporthe grisea), sheath blight (Rhizoctonia solani), Bakanae disease (Fusarium moniliformae), false smut (Ustilaginoidea virens) and brown spot (Helminthosporium oryzae) (Ou 1985). To identify and prioritize major rice diseases in kymore plateau and stapura zone and to determine the prevalence and distribution of these diseases in the area.

\section{Materials and Methods}

\section{Description of the study area}

Observations on incidence of rice diseases at six different locations around Jabalpur viz. Panagar, Maharajpur, Patan road, Damoh road, Tilwara, Bhedaghat and also in Seed production unit field Jabalpur at COA, JNKVV Jabalpur were recorded through random plot and fixed field survey method.
The incidence of diseases was recorded during II fortnight of October to II fortnight of November. The investigations were conducted in rice crop, that lies between $22^{0} 21^{\prime}$ and $80^{0} 58^{\prime}$ East longitude at an altitude 411.78 meter above the mean sea level and average temperature prevailing was $24.11^{\circ} \mathrm{C}$ and relative humidity was $63.6 \%$.

\section{Random plot survey}

In random plot survey method implementation of zigzag manner of making $\mathrm{W}$ shaped path has done in a particular field. The surveys were timed to coincide with crop growth stages viz., vegetative growth, heading stage, panicle initiation stage in all fields sampled.

The incidence for fungal and bacterial disease was made on the basis of typical visual symptoms. 100 randomly selected plants were taken as sample size for observations of incidence of diseases. Based upon randomly selected plants, diseases were observed in natural field conditions. The disease symptoms on leaves, sheath and panicle were recorded on the basis of typical visual field symptoms.

\section{Fixed field survey}

The fixed field survey was conducted at the Research Experiment Seed Production Unit, JNKVV, Jabalpur. Incidence of major fungal foliage diseases and bacterial foliage diseases of rice at under fixed plot survey. Observation was taken in the crop, including different varieties, JR 201, IR 36, IR 64, Kranti, Mahamaya.

\section{Measurement of disease}

The percent disease incidence (PDI) was calculated by the formula advocated by Singh and Singh (2000). 


$$
\text { PDI }=\frac{\text { Number of diseased plants }}{\text { Total number of plants observed }} \times 100
$$

The symptoms, of target diseases were noticed under field conditions. Target diseases included the sheath blight, blast, brown spot, false smut and BLB. These diseases have been selected on the basis of previous experience the incidence of diseases was observed on the basis of typical field symptoms and later the association was confirmed through microscopic examinations under lab condition.

\section{Results and Discussion}

Investigations were made to determine the status of major targeted diseases of rice in different locations grown in agro climatic conditions of Jabalpur. The incidence of diseases was observed on the basis of typical field symptoms.

\section{Identification of diseases at field level}

On the basis of typical symptoms the brown spot, sheath blight, rice blast false smut and bacterial leaf blight were identified under field conditions.

\section{Sheath blight (Rhizoctonia solani)}

Typical brown elongated irregular shaped lesions were recorded on the sheath, at the base of culms near ground level. Initially the lesions on the sheath were green gray, forming oval or ellipsoidal discoloration, with the advancement of time the color of the lesion became light and dark brown. Later on, the lesions enlarged and the development of the disease was evident. The different oval shape lesion mixed together and encircled the sheath and spread over leaf blade. Many times the lesion was oblong, greenish and brown colored. The similar patterns of lesions were noticed on leaf blade and the infection the developing seeds. A brown discoloration was noticed on panicle. At later stage, minute sclerotia were formed on the infected lesions on sheath base (Figure 1).

\section{Brown spot (Helminthosporium oryzae)}

The symptoms on the foliage incited by brown spot pathogen were conspicuous. On the leaves, the spots varied in size and shape. Typical eye-shape and oval lesions were distinct and fairly scattered over the leaf blade. The smaller spots were of dark brown in color. The larger spots were of dark brown at edge however, towards the centre those were pale yellow and dirty white. Severely affected leaves turned brown and dried out. Black spots appeared on the glumes and gradually spread over. The seeds from severely infected plants were shriveled and discolored (Figure 2).

\section{False smut (Ustilaginoidea virens)}

Usually the symptoms of false smut were confined to the panicles. As a result of infection the individual seed in rice was transformed and developed in to the greenish velvety spore ball. Later on, the yellow greenish spore mass turned in to black mass. At early stage of infection, the spore ball was covered with a transparent membrane that ruptured due to the pressure of spores and liberated. The disease could be identified from a distance on the basis of the presence of spore balls attached with the panicles (Figure 3).

\section{Rice blast (Magnaporthe grisea)}

The pathogen infected all the parts from seedling in nursery stage to heading in main field. The typical symptom appeared on leaves, leaf sheath, nodes and even the glumes were also infected. In case of leaf blast, the lesions started as small water soaked bluish green specks, soon enlarged and formed characteristic spindle shaped spots with grey 
centre. At flower emergence, the fungus attacked the peduncle which was engirdled, and the lesions turned to brownish black. This stage of infection is commonly referred to as rotten neck. A total loss of panicle was noticed (Figure 4).

\section{Bacterial leaf blight (Xanthomonas oryzae pv. oryzae)}

The disease was noticed at the time of heading. In grown up plants, water soaked, translucent lesions appeared near the leaf margin. The lesions enlarged both in length and width with a wavy margin and turned straw yellow within few days, covering the entire leaf. As the disease progresses, the lesions covered the entire leaf blade that turned straw colored. Milky or opaque dew drops containing bacterial masses were formed on young lesions as observed in the early morning. Those dry up on the surface leaving a white encrustation. When the cut end of leaf was dipped in water, bacterial ooze makes the water turbid. Oozing was also noticed from the cut end of leaves, as observed under microscopic examination (Figure 5).

\section{Bunt (Tilletia barclayana)}

Infected grains exhibited very small black pustules or streaks bursting through the glumes. When infection was severe, rupturing glumes produced a short beak-like outgrowth and the entire grain was replaced by powdery black mass of smut spores. Very few grains were recorded in a panicle (Figure 6).

\section{Grain discoloration}

Grain discoloration of rice is a complex disease problem due to infection by microorganisms on glumes, kernels or both. The fungi that are associated with discoloration of grains are Bipolaris
(=Drechslera) oryzae, Alternaria padwickii, Alternaria alternata, Pyricularia oryzae, Fusarium moniliformae, Fusarium graminaerum, Nigrospora oryzae, Epicoccum nigrum, Curvularia lunata, Phoma sorghina, Aspergillus niger and Aspergillus flavus (Figure 7).

\section{Status of diseases}

Data presented in Table 1 indicate that sheath blight was a major wide spread disease. The incidence of sheath blight ranged up to $40.0 \%$ as observed in the fields at Bhedaghat village. Observations were recorded on randomly selected 50 plants in a particular field of that location. In each village five randomly road side rice fields were selected. The incidence of sheath blight was also higher in Panagar and Maharajpur. In Panagar the incidence of sheath blight ranged from 15.0-35.0 \% . Least incidence was noticed in rice fields at Damoh road and Tilwara.

In all the incidence of leaf blast was noticed up to $17.0 \%$, being maximum in Bhedaghat. The incidence of leaf blast was comparatively lower in all other location. Least number of infected plants were observed in Maharajpur, Patan road, Damoh road and Tilwara. Incidence of brown spot was widespread at all the locations under study and it ranged from 3.0-25.0\%. The incidence of brown spot was higher in fields of Panagar village (3.0 to 25.0 $\%$ ) (Table 1). In majority of the rice fields of Damoh road and Tilwara, the incidence of brown spot was comparatively low. About $50 \%$ fields were free from brown spot infection in Damoh and Tilwara.

The incidence of BLB was confirmed on the basis of typical symptoms under field conditions and it ranged from $2.0-12.0 \%$. The disease was not recorded in Maharajpur. About half of the fields of Damoh road and Tilwara were free from infection. 
Table.1 Incidence of major diseases of rice at farmer's field around Jabalpur

\begin{tabular}{|c|c|c|c|c|}
\hline \multirow[t]{2}{*}{ Location } & \multicolumn{4}{|c|}{ Per cent disease incidence } \\
\hline & Sheath blight & Leaf blast & Brown spot & BLB \\
\hline \multicolumn{5}{|l|}{ Panagar } \\
\hline Field.01. & 35.0 & 07.0 & 19.0 & 03.0 \\
\hline Field.02. & 30.0 & 03.0 & 15.0 & 00.0 \\
\hline Field.03. & 21.0 & 00.0 & 23.0 & 05.0 \\
\hline Field.04. & 15.0 & 00.0 & 25.0 & 02.0 \\
\hline Field.05. & 29.0 & 04.0 & 03.0 & 00.0 \\
\hline \multicolumn{5}{|c|}{ Maharajpur } \\
\hline Field.01. & 20.0 & 00.0 & 12.0 & 00.0 \\
\hline Field.02. & 23.0 & 00.0 & 13.0 & 00.0 \\
\hline Field.03. & 17.0 & 00.0 & 00.0 & 00.0 \\
\hline Field.04. & 12.0 & 04.0 & 00.0 & 00.0 \\
\hline Field.05. & 19.0 & 03.0 & 00.0 & 00.0 \\
\hline \multicolumn{5}{|c|}{ Patan road } \\
\hline Field.01. & 17.0 & 00.0 & 05.0 & 04.0 \\
\hline Field.02. & 12.0 & 05.0 & 00.0 & 03.0 \\
\hline Field.03. & 34.0 & 06.0 & 22.0 & 00.0 \\
\hline Field.04. & 05.0 & 00.0 & 20.0 & 12.0 \\
\hline Field.05. & 03.0 & 00.0 & 15.0 & 00.0 \\
\hline \multicolumn{5}{|c|}{ Damoh road } \\
\hline Field.01. & 00.0 & 11.0 & 00.0 & 00.0 \\
\hline Field.02. & 00.0 & 05.0 & 00.0 & 00.0 \\
\hline Field.03. & 20.0 & 00.0 & 00.0 & 00.0 \\
\hline Field.04. & 11.0 & 00.0 & 05.0 & 05.0 \\
\hline Field.05. & 00.0 & 00.0 & 19.0 & 03.0 \\
\hline \multicolumn{5}{|c|}{ Tilwara } \\
\hline Field.01. & 00.0 & 05.0 & 00.0 & 10.0 \\
\hline Field.02. & 00.0 & 00.0 & 15.0 & 12.0 \\
\hline Field.03. & 05.0 & 00.0 & 13.0 & 00.0 \\
\hline Field.04. & 07.0 & 00.0 & 10.0 & 00.0 \\
\hline Field.05. & 10.0 & 03.0 & 00.0 & 00.0 \\
\hline \multicolumn{5}{|c|}{ Bhedaghat } \\
\hline Field.01. & 11.0 & 10.0 & 00.0 & 00.0 \\
\hline Field.02. & 12.0 & 17.0 & 12.0 & 00.0 \\
\hline Field.03. & 19.0 & 00.0 & 00.0 & 05.0 \\
\hline Field.04. & 40.0 & 01.0 & 04.0 & 04.0 \\
\hline Field.05. & 20.0 & 02.0 & 03.0 & 02.0 \\
\hline Range & $03.0-40.0$ & $01.0-17.0$ & $03.0-25.0$ & $02.0-12.0$ \\
\hline
\end{tabular}

Observations during II fortnight of October - II fortnight of November Average Temperature $24.11^{\circ} \mathrm{C}$ and Relative Humidity $63.6 \%$ 
Table.2 Incidence of major diseases of rice at farmers fields around Jabalpur during random plot survey in Kharif

\begin{tabular}{|c|c|c|c|c|}
\hline \multirow[t]{2}{*}{ Location } & \multicolumn{4}{|c|}{ Per cent disease incidence } \\
\hline & Neck blast & False smut & Grain discoloration & Bunt \\
\hline \multicolumn{5}{|c|}{ Panagar } \\
\hline Field.01. & 08.0 & 19.0 & 15.0 & 0.00 \\
\hline Field.02. & 06.0 & 13.0 & 06.0 & 0.00 \\
\hline Field.03. & 00.0 & 25.0 & 11.0 & 0.00 \\
\hline Field.04. & 00.0 & 20.0 & 17.0 & 0.00 \\
\hline Field.05. & 00.0 & 11.0 & 00.0 & 0.00 \\
\hline \multicolumn{5}{|c|}{ Maharajpur } \\
\hline Field.01. & 00.0 & 05.0 & 00.0 & 0.00 \\
\hline Field.02. & 00.0 & 00.0 & 00.0 & 0.00 \\
\hline Field.03. & 00.0 & 00.0 & 00.0 & 0.00 \\
\hline Field.04. & 05.0 & 04.0 & 13.0 & 0.00 \\
\hline Field.05. & 02.0 & 13.0 & 0.00 & 0.00 \\
\hline \multicolumn{5}{|c|}{ Patan road } \\
\hline Field.01. & 00.0 & 15.0 & 00.0 & 0.00 \\
\hline Field.02. & 03.0 & 19.0 & 05.0 & 0.00 \\
\hline Field.03. & 06.0 & 25.0 & 10.0 & 0.00 \\
\hline Field.04. & 00.0 & 22.0 & 08.0 & 0.00 \\
\hline Field.05. & 00.0 & 13.0 & 00.0 & 0.00 \\
\hline \multicolumn{5}{|c|}{ Damoh road } \\
\hline Field.01. & 10.0 & 05.0 & 10.0 & 0.00 \\
\hline Field.02. & 03.0 & 00.0 & 15.0 & 0.00 \\
\hline Field.03. & 00.0 & 00.0 & 00.0 & 0.00 \\
\hline Field.04. & 00.0 & 04.0 & 00.0 & 0.00 \\
\hline Field.05. & 00.0 & 00.0 & 00.0 & 0.00 \\
\hline \multicolumn{5}{|c|}{ Tilwara } \\
\hline Field.01. & 00.0 & 15.0 & 00.0 & 0.00 \\
\hline Field.02. & 00.0 & 13.0 & 00.0 & 0.00 \\
\hline Field.03. & 00.0 & 25.0 & 00.0 & 0.00 \\
\hline Field.04. & 00.0 & 22.0 & 00.0 & 0.00 \\
\hline Field.05. & 00.0 & 10.0 & 05.0 & 0.00 \\
\hline \multicolumn{5}{|c|}{ Bhedaghat } \\
\hline Field.01. & 07.0 & 11.0 & 10.0 & 0.00 \\
\hline Field.02. & 10.0 & 00.0 & 12.0 & 0.00 \\
\hline Field.03. & 00.0 & 00.0 & 07.0 & 0.00 \\
\hline Field.04. & 00.0 & 17.0 & 05.0 & 0.00 \\
\hline Field.05. & 00.0 & 20.0 & 16.0 & 0.00 \\
\hline Range & $02.0-10.0$ & $04.0-25.0$ & $05.0-17.0$ & 0.00 \\
\hline
\end{tabular}

Observations during II fortnight of October - II fortnight of November Average Temperature $24.11^{\circ} \mathrm{C}$ and Relative Humidity $63.6 \%$ 
Table.3 Incidence of major diseases of rice at JNKVV Seed Production units observed during random plot survey

\begin{tabular}{|c|c|c|c|c|c|}
\hline \multirow[t]{2}{*}{ Location } & \multicolumn{5}{|c|}{ Per cent disease incidence } \\
\hline & Sheath blight & Leaf blast & Brown spot & BLB & \\
\hline \multicolumn{6}{|c|}{ Adhartal tank farm } \\
\hline JR 201 & 05.0 & 02.0 & 12.0 & 00.0 & \\
\hline IR 36 & 19.0 & 00.0 & 15.0 & 02.0 & \\
\hline IR 64 & 15.0 & 10.0 & 17.0 & 00.0 & \\
\hline Kranti & 40.0 & 00.0 & 22.0 & 05.0 & \\
\hline Mahamaya & 32.0 & 00.0 & 10.0 & 04.0 & \\
\hline \multicolumn{6}{|c|}{ Krishi nagar farm } \\
\hline IR 36 & 10.0 & 05.0 & 15.0 & 02.0 & \\
\hline IR 64 & 30.0 & 05.0 & 00.0 & 00.0 & \\
\hline Kranti & 35.0 & 03.0 & 17.0 & 00.0 & \\
\hline \multicolumn{6}{|c|}{ Maharajpur farm } \\
\hline IR 36 & 25.0 & 05.0 & 12.0 & 04.0 & \\
\hline IR 64 & 10.0 & 04.0 & 05.0 & 00.0 & \\
\hline Kranti & 23.0 & 10.0 & 19.0 & 00.0 & \\
\hline \multicolumn{6}{|c|}{ Agricultural Engineering farm } \\
\hline JR 201 & 05.0 & 03.0 & 05.0 & 03.0 & \\
\hline IR 36 & 16.0 & 10.0 & 03.0 & 00.0 & \\
\hline IR 64 & 10.0 & 00.0 & 05.0 & 00.0 & \\
\hline$\overline{\text { Kranti }}$ & 35.0 & 18.0 & 21.0 & 04.0 & \\
\hline Mahamaya & 20.0 & 10.0 & 20.0 & 05.0 & \\
\hline Range & $05.0-40.0$ & $02.0-18.0$ & $03.0-22.0$ & 02.0 & -05.0 \\
\hline
\end{tabular}

Observations during II fortnight of October - II fortnight of November 2015

Average temperature $24.11^{\circ} \mathrm{C}$ and Relative Humidity 
Table.4 Incidence of major diseases of rice at JNKVV Seed Production units observed during random plot survey

\begin{tabular}{|c|c|c|c|}
\hline \multirow[t]{2}{*}{ Location } & \multicolumn{3}{|c|}{ Per cent disease incidence } \\
\hline & Neck blast & False smut & $\begin{array}{c}\text { Grain } \\
\text { discoloration }\end{array}$ \\
\hline \multicolumn{4}{|c|}{ Adhartal tank farm } \\
\hline JR 201 & 00.0 & 10.0 & 05.0 \\
\hline IR 36 & 00.0 & 10.0 & 10.0 \\
\hline IR 64 & 10.0 & 12.0 & 15.0 \\
\hline Kranti & 12.0 & 12.0 & 19.0 \\
\hline Mahamaya & 00.0 & 07.0 & 00.0 \\
\hline \multicolumn{4}{|c|}{ Krishi Nagar farm } \\
\hline IR 36 & 00.0 & 05.0 & 06.0 \\
\hline IR 64 & 03.0 & 04.0 & 00.0 \\
\hline Kranti & 07.0 & 10.0 & 12.0 \\
\hline \multicolumn{4}{|c|}{ Maharajpur farm } \\
\hline IR 36 & 00.0 & 00.0 & 05.0 \\
\hline IR 64 & 00.0 & 00.0 & 07.0 \\
\hline Kranti & 15.0 & 05.0 & 15.0 \\
\hline \multicolumn{4}{|c|}{ Agricultural Engineering farm } \\
\hline JR 201 & 00.0 & 07.0 & 03.0 \\
\hline IR 36 & 05.0 & 02.0 & 02.0 \\
\hline IR 64 & 02.0 & 14.0 & 00.0 \\
\hline Kranti & 13.0 & 15.0 & 17.0 \\
\hline Mahamaya & 05.0 & 03.0 & 15.0 \\
\hline Range & $02.0-15.0$ & $02.0-15.0$ & $02.0-19.0$ \\
\hline
\end{tabular}

Observations during II fortnight of October - II fortnight of November 2015

Average Temperature $24.11^{\circ} \mathrm{C}$ and Relative Humidity $63.6 \%$

\section{Field survey}

Random field survey

Fixed field survey
At farmers field of Panagar, Maharajpur, Patan road, Damoh road, Tilwara, Bhedaghat Seed production unit field Jabalpur at COA, JNKVV Jabalpur 
Int.J.Curr.Microbiol.App.Sci (2018) 7(11): 2240-2252

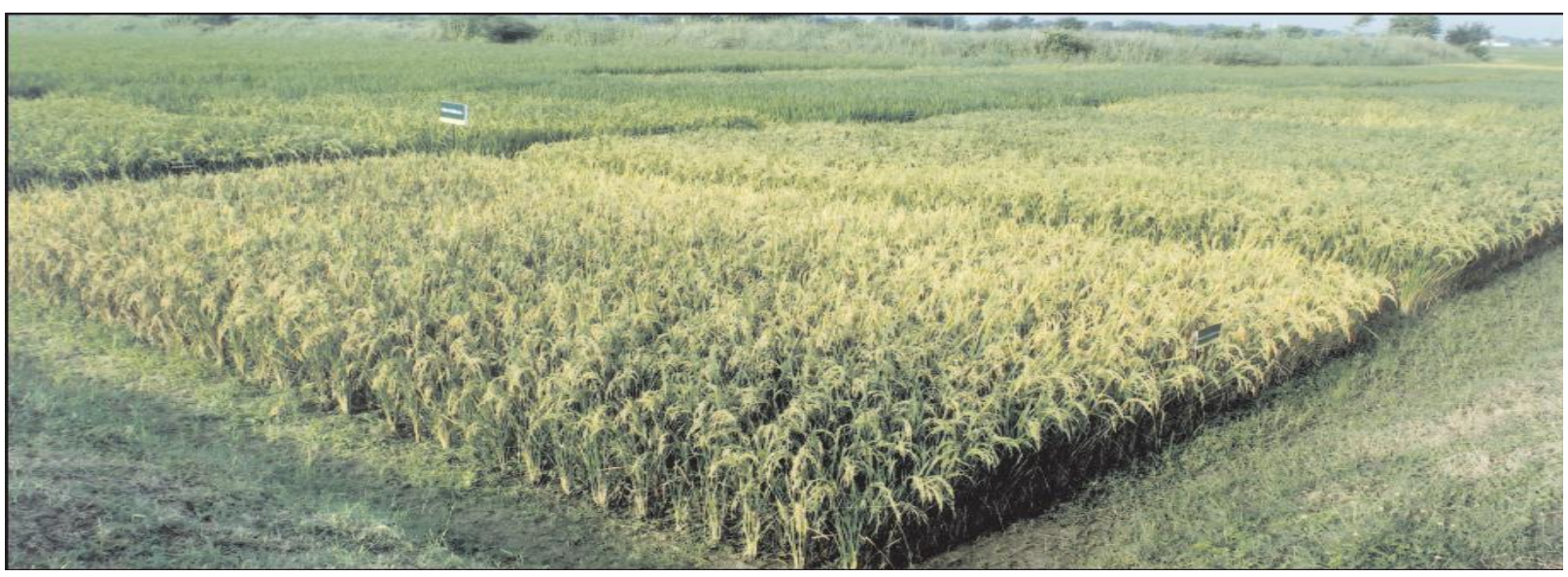

Seed production unit field, COA, JNKVV Jabalpur

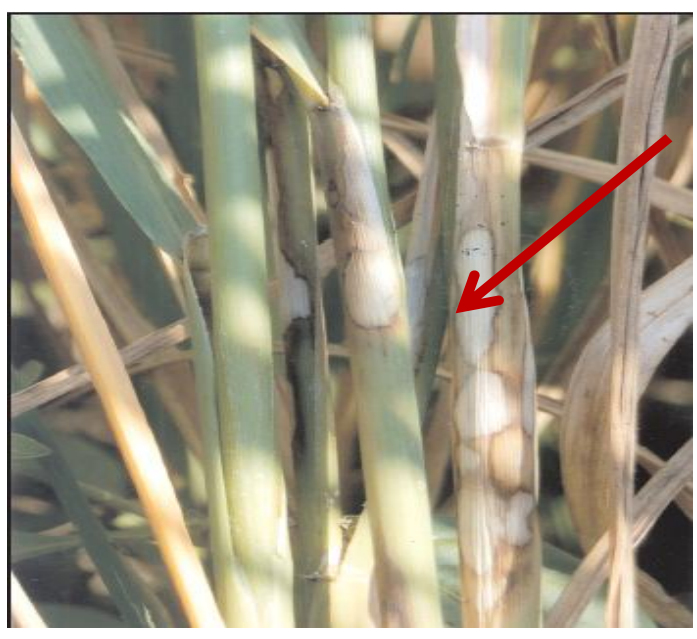

Fig I : Sheath blight

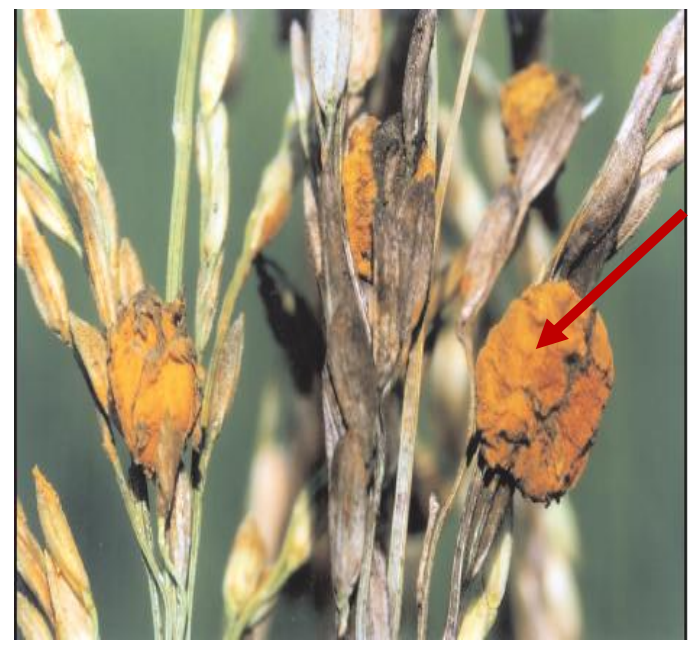

Fig III : False smut

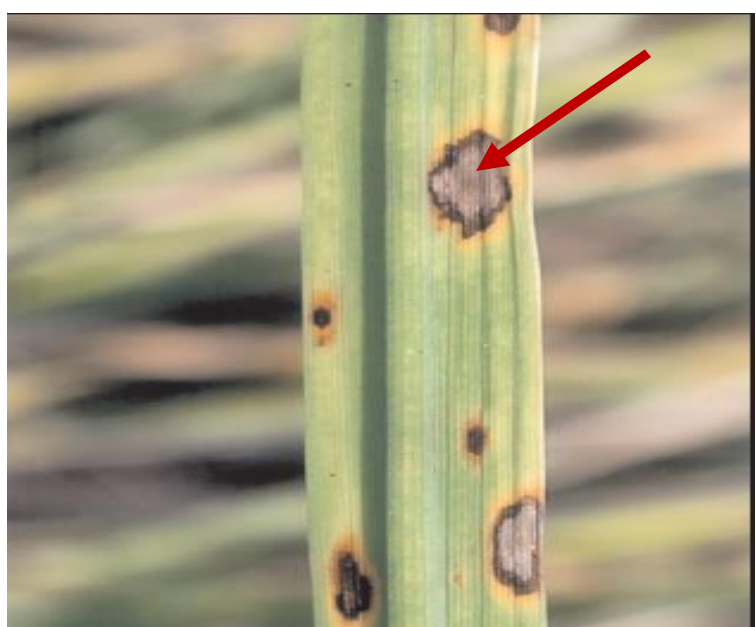

Fig II : Brown snot

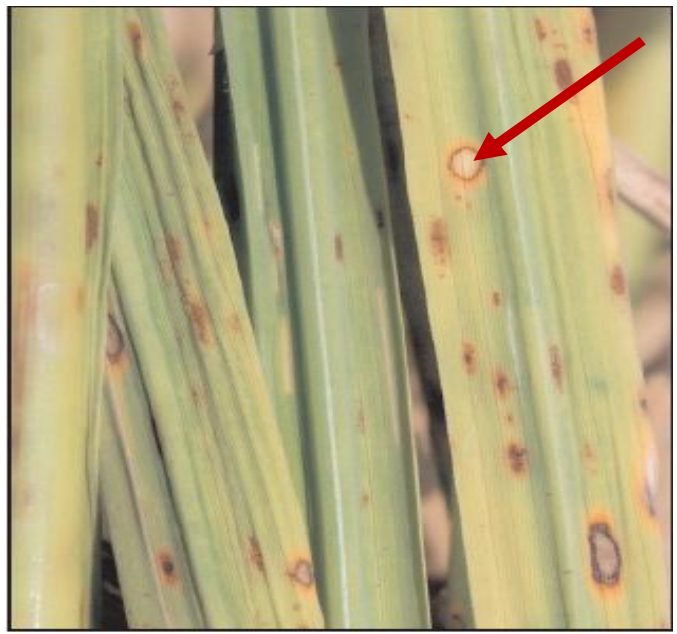

Fig IV : Rice blast 


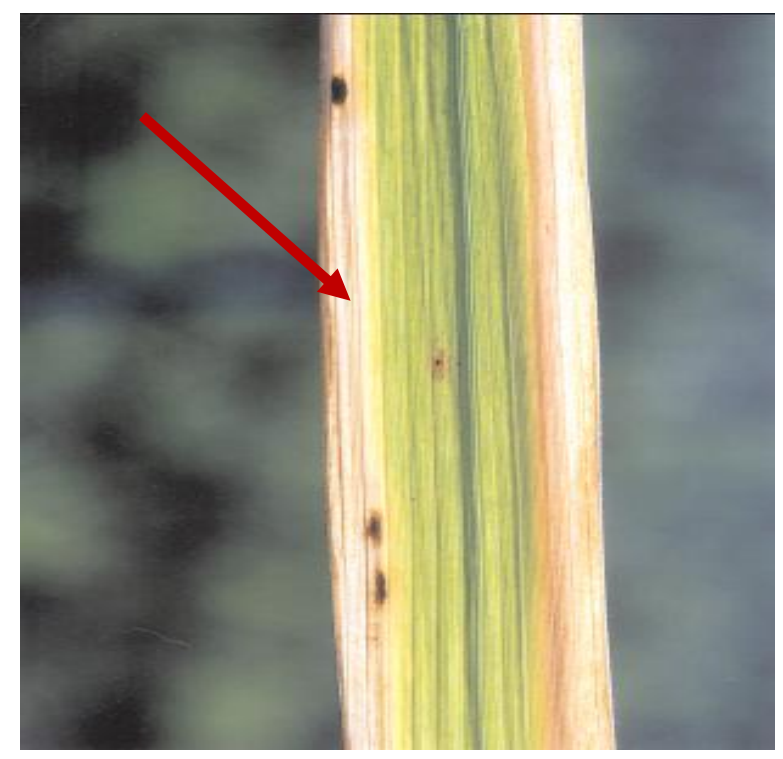

Fig V : Bacterial leaf blight
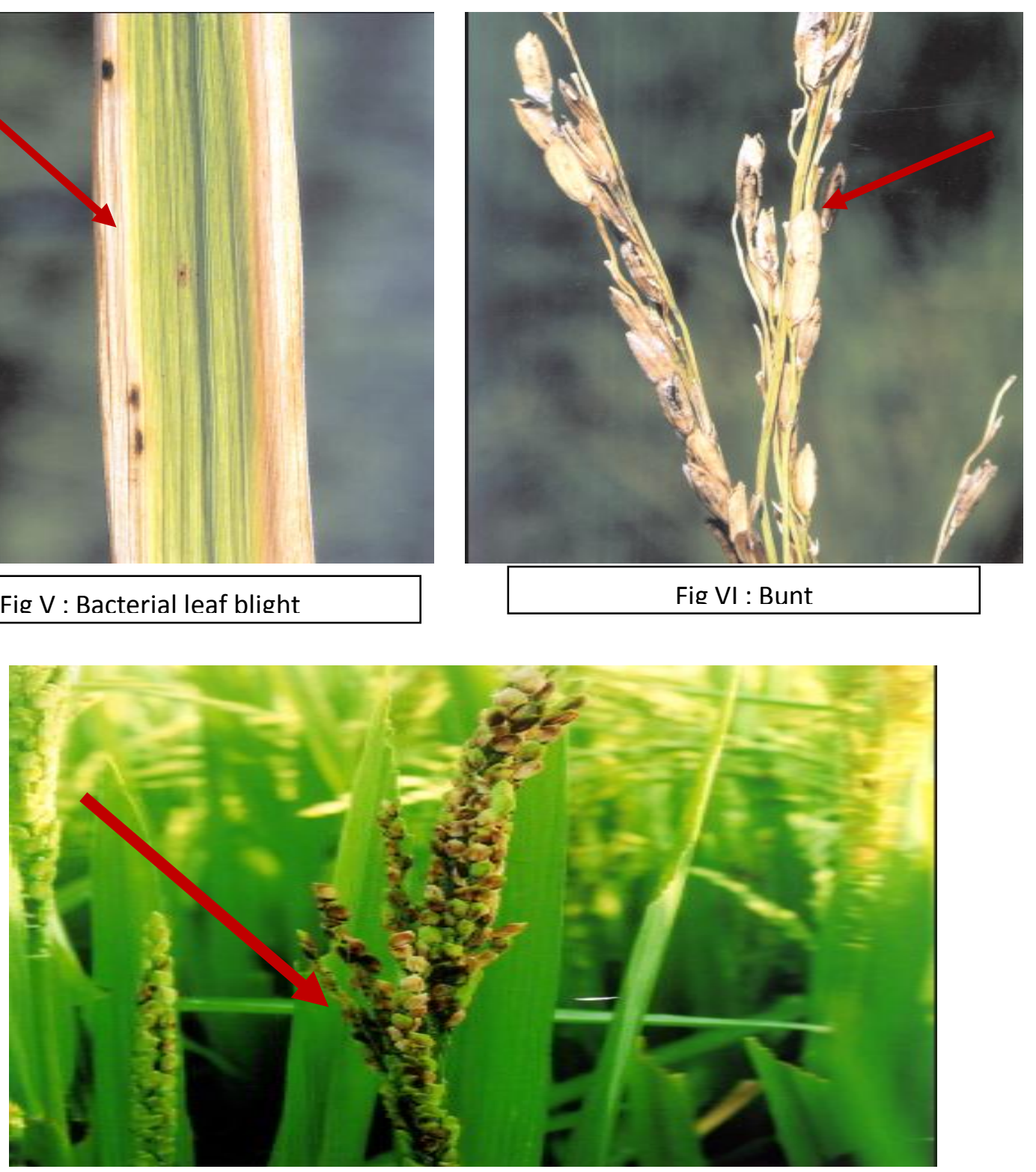

Fig VII : Grain discoloration

The incidence of false smut ranged from 4.0 to $25.0 \%$. Maximum incidence of false smut was observed in fields of Panagar, Patan and Tilwara. The disease was identified on the basis of characteristic smut balls. The incidence of false smut was comparatively lower in fields of Maharajpur, Damoh road and Bhedaghat. Grain discoloration was observed in range of $5.0-17.0 \%$ at six locations. In fields of Panagar the incidence of grain discoloration ranged from 6.0-17.0\% and $5.0-16.0 \%$ in Bhedaghat. The incidence of neck blast was observed in one field of Damoh road and Bhedaghat in the range of 7.0- $10.0 \%$ (Table 2).

\section{Seed production fields}

Incidence of rice diseases was recorded in five varieties grown at four rice Seed 
Production units of JNKVV. Incidence of diseases was recorded in 100 randomly selected plants during II fortnight of October to II fortnight of November. In all, seven diseases were recorded.

In Adhartal Tank Farm, incidence of seven diseases was noticed infecting five rice varieties. The incidence of sheath blight was maximum (40.0\%) in Kranti followed by $32.0 \%$ (Mahamaya) and 19\% (IR 36). Leaf blast was not observed in IR 36, Kranti and Mahamaya. Incidence of leaf blast was higher in IR $64(10.0 \%)$. Brown spot was wide spread and incidence ranged from $10.0 \%$ (Mahamaya) to $22.0 \%$ (Kranti). BLB was not recorded in JR 201 and IR 64. Maximum incidence of BLB was $5.0 \%$ in Kranti (Table 3).

The prevalence of sheath blight was uniformly distributed and maximum disease was recorded in Kranti $(23.0$ - 35.0\%) grown in Krishi Nagar Farm and Agricultural Engineering Farm. The incidence of leaf blast was maximum $(18.0 \%)$ in Kranti grown at Agricultural Engineering Farm, Jabalpur. The incidence of brown spot ranged from 17.0$22.0 \%$ in variety Kranti. Incidence of BLB ranged from 2.0-5.0\%. In the present investigation it was noticed that, Kranti and Mahamaya were the most susceptible varieties and incidence ranged from 4.0-5.0\%.

Data presented in Table 4 indicate that the grain discoloration was in the range of $2.0-$ $19.0 \%$ in the harvested seeds. The grain discoloration in variety Kranti ranged from $15.0-19.0 \%$. Least grain discoloration was recorded in IR 36 and JR 201 grown at Agricultural Engineering Farm. At Adhartal Tank Farm incidence of grain discoloration ranged from 5.0-19.0\%. In seed production unit, it was observed that JR 201 had lesser grain discoloration problem (3.0-5.0 \%) as compared to IR 36 and Kranti. Higher incidence of false smut was recorded in the rice varieties grown at Adhartal Tank Farm (7.0-12.0\%), while minimum at Maharajpur farm $(5.0 \%)$.

Considering the fact of poor documentation and unsystematic studies on the diseases of rice in the State, present investigation was undertaken to generate basic information, especially for Kymore plateau and satpura zone. It was noticed that under present climatic situations sheath blight is a major wide spread disease. In the previous years, sheath blight had never been a major threat for profitable cultivation of rice. It is concluded that monoculture and intensive agriculture has promoted the buildup of inoculum in soil. The incidence of sheath blight ranged up to $40.0 \%$ as observed in the fields at Bhedaghat village. In all, the incidence of leaf blast (Magnaporthe grisea) was noticed up to $17.0 \%$, being maximum in Bhedaghat.

Incidence of brown spot (Helminthosporium oryzae) was widespread at all the locations under study and it ranged from 3.0-25.0 \%. The incidence of brown spot was higher in fields of Panagar village (3.0 to $25.0 \%$ ). The incidence of BLB ranged from $2.0-12.0 \%$. The incidence of false smut ranged from 4.0 to $25.0 \%$. Maximum incidence of false smut was observed in fields of Panagar, Patan and Tilwara. Grain discoloration was observed in range of $5.0-17.0 \%$ at six locations. The incidence of neck blast was observed in one field of Damoh road and Bhedaghat in the range of $7.0-10.0 \%$. Grain discoloration is problem in the areas where the rains are received during grain filling stage. It is a wide spread region specific threat in Punjab, Tamil Nadu, Andhra Pradesh and Odisha (Anonymous 2014).

Incidence of rice diseases was recorded in five varieties grown at four Rice Seed 
Production units of JNKVV during Kharif 2015. Incidence of diseases was measured in 100 randomly selected plants during II fortnight of October to II fortnight of November. In Adhartal Tank Farm, incidence of seven diseases was noticed infecting five rice varieties. The incidence of sheath blight was maximum (40.0\%) in Kranti followed by $32.0 \%$ (Mahamaya) and 19\% (IR 36). Leaf blast was not observed in IR 36, Kranti and Mahamaya. Brown spot was wide spread and incidence ranged from $10.0 \%$ (Mahamaya) to $22.0 \%$ (Kranti). BLB was not recorded in JR 201 and IR 64.

The prevalence of sheath blight was uniformly distributed and maximum disease was recorded in Kranti $(23.0-35.0 \%)$ grown in Krishi Nagar Farm and Agricultural Engineering Farm. The incidence of leaf blast was maximum $(18.0 \%)$ in Kranti grown at Agricultural Engineering Farm, Jabalpur. The incidence of brown spot ranged from 17.0$22.0 \%$ in variety Kranti. In the investigation it was noticed that, Kranti and Mahamaya were the most susceptible varieties and incidence ranged from $4.0-5.0 \%$. Least grain discoloration was recorded in IR 36 and JR 201 grown at Agricultural Engineering Farm. At Adhartal Tank Farm incidence of grain discoloration ranged from 5.0-19.0\%.

\section{References}

Agarwal VK and Sinclair JB. 1997. Principles of Seed Pathology Vol. I \& II. Boca Roton, Florida, CRC Press. Inc. USA.

Agarwal VK. 1970. Seedborne fungi of rice, wheat, black gram, green gram and soybean grown at G.B. Pant agricultural University Farm, Pantnagar, India. Research Monograph, Danish Govt. Institute of Seed Pathology for Developing Countries, Copenhagen. 40.
Anonymous. 2007. Annual Report, ICAR All India Coordinated Rice Improvement Project, New Delhi.

Anonymous. 2007. Hand Book of Agriculture, ICAR, New Delhi. 1009p.

Anonymous. 2013. Madhya Pradesh Agriculture Statistics Directorate M.P.

Benoit MA and Mathur SB. 1970. Identification of species of Curvularia on rice seed. Proceedings on International Seed Testing Association. 35: 99-119.

Biswas A. 2001. False smut disease of rice: a review. Indian Environment and Ecology. 19(1): 67-83.

Chiba S, Chiba J, Shimada K and Kangw H. 1972. Epidemiological studies on rice blast. Annual Phytopathology Society. Japan. 38(4): 299-305.

Chidambaram P, Mathur SB and Neergaard. 1973. Identification of seed borne Drechslera species, Friesia. 10: 165207.

Dhal A, Mohanty and Lenka AK. 1998. Occurrence of sheath blight rot of rice in semi deep water situation in Orissa. Indian Environment \& Ecology. 16(1): 233-234.

Ducanes AA, Pedroso JP and Yumol RD. 1994. Screening of rice/ selections/ varieties for resistance to brown spot (Heminthosporium oryzae) in Zamboanga city (Wet season, 1992) (Phillippines). Integrated pest management: Learning from Experience College, Laguna (Philippines). 76-77.

IRRI. 2008. International Rice Research Institute. The Rice plant and how it grow (http://enWikipedia org wiki/Riceplant).

Kapse VV. 2009. Status, Distribution and Epidemiology of Diseases of rice and hybrids. M.Sc. (Ag) Thesis, Department of Plant Pathology, JNKVV, Jabalpur. 99p. 
Leano RM, Castilla NP, Lapis DB and Savary S. 1993. A simple methodology for analyzing rice sheath blight $(\mathrm{ShB})$ epidemiologic processes under semicontrolled conditions. International Rice Research Notes. 18(3): 42p.

Mew TW and Gonzales P. 2002. A Handbook of Rice Seedborne Fungi. 83p.

Nagrajan S and Murlidharan K. 1995. Dynamics of Plant Diseases. Allied Publishers Ltd, Hyderabad (AP). 247p.

Padhi B and Gangopadhyay S. 1998. Diseases of rice and their management. National Agricultural Technology Information Centre, Punjab Agricultural University, Ludhiana. 35-51.

Pannu PPS, Kour M and Chahal SS 2006. Occurrence of false smut of rice, its effect grain yield and its control. Plant Disease Research. 21(2): 215-216.

Reddy MM, Reddy CS, Reddy AG. 2001. Influence of weather parameters and insect pest populations on incidence and development of sheath rot of rice. Indian Phytopathology. 54(2): 179-184.

Sharma SR. Singh DN, Singh GP and Gupta SC. 1996. Incidence of eye leaf spot disease of sugarcane caused by Helminthosporium tetramera. Cooperative Sugar. 27 (8): 601-603.
Singh KD, Borkakati and Pathak AK. 2000. Evaluation of hybrid rice for disease resistance against bacterial blight, sheath blight and grain discoloration. Annual Biology. 16(2): 163-166.

Singh RA and Pavgi MS. 1970. Varietal reaction and resistance to kernel smut of rice. Indian Phytopathology. 23: pp5153.

Singh RA and Sharma VV 1975. Evaluation of rice germplasm and varieties for resistance to brown spot. ILRISO. 24: 383p.

Upadhyay RK. 1985. Rice disease status in India. International Rice Research Newsletter. Philippines. 10(5): 17-18.

Vishnavat, Karuna. 2009. Fundamentals of seed pathology. Kalyani Publishers, New Delhi. 280p.

Vishwanathan $R$ and Narayanaswamy $P$. 1990. Chemical control of brown leaf spot of rice. Indian Journal of Mycology and Plant Pathology. 20: 139p.

Yumol R, Pedroso JP and Ducanes AA. 1994. Screening of rice selection/ varieties for resistance to brown spot (Helminthosporium oryzae), dry season, pest management council of Phillippines, Incorporation College, Laguna (Phillippines). 78p.

\section{How to cite this article:}

Ramya Teja, T., Prahallad Masurkar, M.S. Bhale and Koutu, G.K. 2018. Assessment on Prevalence and Distribution of Diseases of Rice in Kymore Plateau and Satpura Zone of Madhya Pradesh. Int.J.Curr.Microbiol.App.Sci. 7(11): 2240-2252.

doi: https://doi.org/10.20546/ijcmas.2018.711.251 